\title{
Entwurf und Bemessung von Tragwandgebäuden unter Erdbebeneinwirkung
}

\section{Doctoral Thesis}

\section{Author(s):}

Dazio, Alessandro

Publication date:

2000

Permanent link:

https://doi.org/10.3929/ethz-a-004004711

Rights / license:

In Copyright - Non-Commercial Use Permitted 
Diss. ETH Nr. 13739

\title{
Entwurf und Bemessung von Tragwandgebäuden unter Erdbebeneinwirkung
}

\author{
ABHANDLUNG \\ zur Erlangung des Titels \\ DOKTOR DER TECHNISCHEN WISSENSCHAFTEN \\ der \\ EIDGENÖSSISCHEN TECHNISCHEN HOCHSCHULE ZÜRICH
}

\author{
vorgelegt von \\ Alessandro Dazio \\ dipl. Bau-Ing. ETH \\ geboren am 9. Februar 1970 \\ von Fusio TI
}

aufgenommen auf Auftrag von

Professor Dr. Hugo Bachmann, Referent

Professor Dr. Dr. h.c. Thomas Paulay, Korreferent 


\section{Kurzfassung}

Entwurf und Bemessung von Bauwerken unter Erdbebeneinwirkung erweisen sich oft als anspruchvolle und heikle Aufgaben. Gründe dafür sind sowohl die dynamische Natur der Einwirkung und deren erschwerte Erfassbarkeit, als auch die zyklische Beanspruchung der verwendeten Baustoffe bis weit in den inelastischen Bereich hinein. Mit der vorliegenden Arbeit sollen dem praktisch tätigen Ingenieur einerseits Aspekte der Einwirkung Erdbeben in anschaulicher Weise nähergebracht, und andererseits Werkzeuge bereitgestellt werden, die bei Entwurf und Bemessung von Stahlbetontragwandgebäuden unter Erdbebeneinwirkung hilfreich sein können.

Die Erfassung der dynamischen Antwort eines Tragwerks ist dabei von zentraler Bedeutung. Deshalb wurden zu Beginn der Arbeit einige dafür geeignete, gängige M ethoden diskutiert. Gerade bei grossem Duktilitätsbedarf bestätigt sich dabei, dass diese Erfassung mit erheblichen Unsicherheiten behaftet ist.

Unter Erdbebeneinwirkung entstehen Gebäudeschäden durch aufgezwungene Verformungen Letztere sollten deshalb im Rahmen der Bemessung verlässlich vorhergesagt und berücksichtigt werden können. Dazu wird hier ein verformungsorientiertes $\mathrm{Be}$ messungsverfahren für kapazitätsbemessene Stahlbetontragwandgebäude vorgeschlagen. Das Verfahren basiert auf akzeptierten Tragwerksverformungen, vor allem auf der maximalen Stockwerksschiefstellung. Zudem berücksichtigt es die effektive Masse und Steifigkeit des Gebäudes sowie die Rahmenwirkung, die aus dem Zusammenwirken von Wänden, Stützen und Decken entsteht. Das Verfahren ist iterativ und ermöglicht deshalb das Erkennen der relativen Bedeutung wichtigsten Bemessungsparameter sowie eine schrittweise Optimierung des Tragwerks. Vergleiche mit nichtlinearen numerischen Berechnungen zeigen, dass das vorgeschlagene Bemessungsverfahren die zu erwartenden Tragwerksverformungen gut erfasst.

Eigene grossmassstäbliche Versuche an kapazitätsbemessenen Stahlbetontragwänden haben den Einfluss von wenig duktilem Bewehrungsstahl auf die Stabilität der gedrückten Längsbewehrung in den Wandendbereichen gezeigt. Schon bei beschränkter Bemessungsduktilität können ernsthafte Stabilitätsprobleme auftreten. In dieser A rbeit werden Formeln vorgeschlagen, um den Abstand und den Querschnitt der Stabilisierungsbewehrung so festzulegen, dass die Längsbewehrung nicht mehr ausknickt. Dabei werden die Duktilitätseigenschaften des Bewehrungsstahls und die baulichen Ungenauigkeitenberücksichtigt.

Die gleichen Versuche zeigten auch, dass Wände, deren Biegewiderstand hauptsächlich durch eine grosse N ormal kraft erzeugt wird, nur ein beschränktes Energiedissipationsvermögen aufweisen. Hier konnte jedoch gezeigt werden, dass diese Erscheinung erst bei grossen Verschiebeduktilitäten wichtig wird, und dass bei beschränkter Verschiebeduktilität die Verwendung solcher Wände sogar empfehlenswert ist.

Neben experimentellen und theoretischen Betrachtungen wurden intensive numerische Studien durchgeführt. Dazu wurde ein massgefertigtes Finite Elemente Programm für die zyklisch-statische und -dynamische Berechnung von inelastischen ebenen Stahlbetontragwerken entwickelt. Das Programm "Rechenbrett 2D" hat sich sowohl bei der Nachrechnung von Versuchen als auch bei der Durchführung von Parameterstudien sehr gut bewährt. 


\section{Abstract}

The seismic design of buildings is often a demanding and delicate task. On the one hand the dynamic nature of earthquake action makes it hard to forecast and handle it. On the other hand it is difficult to describe the cyclic behavior of building materials strained far into their inelastic range.

The present work should help the design engineer in two ways: it should give a practical insight in topics of seismic design and it should provide tools which can be helpful for the design of reliable reinforced concrete structural walls buildings.

It is therefore of great importance to correctly account for the dynamic response of structures during intense ground shaking. The thesis summarizes a number of suitable methods to determine the structural response and shows that this task is afflicted with large uncertainties particularly in cases with large ductility demand.

Building darnage during seismic action is typically a consequence of the occurring deformations. That's why it should be possible to predict them reliably during the design process.

In order to reach this goal, a deformation oriented design procedure for capacity designed RC structural wall buildings has been developed. This procedure builds on the accepted deformations of the structure, particularly the accepted story drift and the chosen design ductility. Furthermore it takes into account the effective mass and stiffness of the building as well as the frame action of interacting walls, columns and slabs. The procedure is iterative and makes it therefore possible to recognize the most important design Parameters and to gradually optimize the structure.

Comparisons with nonlinear numeric calculations show that the proposed procedure suitably forecasts structural deformations.

Own large scale tests on RC walls designed according to the rules of capacity design have shown the influence of poor steel ductility properties on the stability of longitudinal reinforcing bars located in the boundary regions of the walls. The present work proposes formulas to design a stabilizing reinforcement to prevent buckling. They take into account the steel ductility properties as well as incidental structural inaccuracies. The large scale tests also showed that the energy dissipation capacity is heavily reduced in cases where a wall's bending strength is mainly due to axial compression. However, the investigation presented here concludes that this relationship is only important in cases of a high ductility demand. Moreover, in cases of limited ductility $\left(\mu_{\Delta}=3\right.$ ), it is even recommended to use such walls.

Experimental and theoretical approaches were complemented by extensive numerical studies. To do so, a tailor-made finite element program called "Rechenbrett 2D" has been developed. It allows the nonlinear static-cyclic and dynamic analysis of RC structures. Its Performance in checking experimental evidence and in parametric studies is very satisfactory. 